NBER WORKING PAPER SERIES

\title{
FORGING A NEW IDENTITY: THE COSTS AND BENEFITS OF DIVERSITY IN CIVIL WAR COMBAT UNITS FOR BLACK SLAVES AND FREEMEN
}

\author{
Dora L. Costa \\ Matthew E. Kahn \\ Working Paper 11013 \\ http://www.nber.org/papers/w11013 \\ NATIONAL BUREAU OF ECONOMIC RESEARCH \\ 1050 Massachusetts Avenue \\ Cambridge, MA 02138 \\ December 2004
}

We have benefited from the comments of John de Figueiredo and of participants at the 2004 Law and Economics NBER Summer Institute and at seminars at the University of California, Berkeley, the University of Toronto, and Harvard. We both gratefully acknowledge the support of NIH grant R01 AG19637 and Dora Costa also gratefully acknowledges the support of NIH grant P01 AG10120, the Robert Wood Johnson Foundation, and the Center for Advanced Study in the Behavioral Sciences. This paper was written in part while the authors were at the Center for Advanced Study in the Behavioral Sciences and the economics department at Stanford University, respectively. The views expressed herein are those of the author(s) and do not necessarily reflect the views of the National Bureau of Economic Research.

(C) 2004 by Dora L. Costa and Matthew E. Kahn. All rights reserved. Short sections of text, not to exceed two paragraphs, may be quoted without explicit permission provided that full credit, including ( $)$ notice, is given to the source. 
Forging a New Identity: The Costs and Benefits of Diversity in Civil War Combat Units for Black Slaves and Freemen Dora L. Costa and Matthew E. Kahn

NBER Working Paper No. 11013

December 2004

JEL No. J24, M12, Z13

\title{
$\underline{\text { ABSTRACT }}$
}

By the end of the Civil War, 186,017 black men had fought for the Union Army and roughly threequarters of these men were former slaves. Because most of the black soldiers who served were illiterate farm workers, the war exposed them to a much broader world. The war experience of these men depended upon their peers, their commanding officers, and where their regiment toured. These factors affected the later life outcomes of black slaves and freemen. This paper documents both the short run costs and long run benefits of participating in a diverse environment. In the short run the combat unit benefited from company heterogeneity as this built social capital and minimized shirking, but in the long run men's human capital and aquisition of information was best served by fighting in heterogeneous companies.

\author{
Dora L. Costa \\ MIT \\ Department of Economics, E52-274C \\ 50 Memorial Drive \\ Cambridge, MA 02142 \\ and NBER \\ costa@mit.edu \\ Matthew E. Kahn \\ The Fletcher School \\ Tufts University \\ Medford, MA 02155 \\ and NBER \\ matt.kahn@tufts.edu
}




\section{Introduction}

In the summer of 1862, two Union Army generals, acting without War Department authorization, formed the first black regiments from fugitive and contraband slaves and from freemen in Louisiana and the South Carolina sea islands. In 1863 the War Department authorized the recruitment of exslaves in the southern areas liberated by the Union Army and of freemen in the north. By the end of 1865, 186,017 blacks had fought for the Union Army and roughly three-quarters of these men were former slaves.

War experience can radically alter the course of one's life. Service in World War II and the Vietnam War lowered later earnings because of lost labor market experience (Angrist and Krueger 1994; Angrist 1990). Employment during mobilization for World War II permanently raised women's labor force participation rates (Acemoglu, Autor, and Lyle 2004).

War service exposed black Civil War soldiers, many of whom were illiterate farm workers, to a much broader world. Ex-slaves faced the challenge of translating their new legal freedom into economic opportunity. A former slave would be more likely to achieve his goals if he was literate and aware of economic opportunities in states he had never lived in. While fighting for the Union Army exposed ex-slaves to combat and disease risk, the Army experience represented a type of "job training" program. The average black soldier who fought in the Civil War and survived served with his unit for 500 days. The "treatment" from participating in this war depended on who were the man's peers and his commanding officer and where his regiment traveled. While these men may have preferred to have as comrades men whose background resembled their own, they may have learned the most from living and fighting in heterogeneous companies and traveling through the nation.

This paper examines the costs and benefits of diversity in black Civil War combat units. Three independent research lines have examined the consequences of diversity for economic outcomes. The recent social capital literature has emphasized the costs of diversity (see Alesina and La Ferrara 
2004 and Durlauf and Fafchamps 2004 for reviews). In a diverse environment, people are more likely to free ride, participate less and be less generous toward others. A second literature has examined the benefits of living and working in a diverse environment. Diversity facilitates learning and information transfer. Building on the ideas of Jane Jacobs, Glaeser, Kallal, Scheinkman and Shleifer (1992) find evidence that more diverse local economies grow faster than more specialized economies. Bowen and Bok (1998) report that alumni from elite schools pointed to their social interactions in college as helping them to relate to members of different racial groups later in life. Guryan (2004) finds that peer effects partially explain the over-all decline in black dropout rates with school desegregation but that white dropout rates remained unaffected. A third research line has examined how diversity within organizations affects outcome measures. Some theoretical work has suggested pathways through which diversity increases organizational efficiency while other studies suggest the opposite. ${ }^{1}$

We use a unique panel data set of over 5000 black Civil War soldiers to document the short run costs to the combat unit of organization diversity and the long run benefits to individual soldiers of diversity. Our data allow us to construct a soldier's local peer group during the war and to follow him after the war until death. The paper first examines how diversity within combat units affected soldiers' loyalty to their units, where loyalty is measured by soldiers' willingness not to desert, go AWOL, or commit other disciplinary infractions. This is our main measure of the costs of diversity. A major benefit of diversity is learning from others' experience. Soldiers from a more diverse company could learn about life in different parts of the country and might be more likely to migrate. Established networks of previous migrants sustain migration flows by providing information and direct assistance in settling in a new area (e.g. Carrington, Detragiache, and

\footnotetext{
${ }^{1}$ The benefits of diversity to organizations include lower costs of adapting to new environments (Carillo and Gromb 2002), advantages gained from employing workers with different attachments to the firm (Fershtman, Hvidel, and Weiss 2003), and the ability to hire from a wider pool of workers (Athey, Avery, and Zemsky 2000). The costs of diversity include less trust between co-workers (Lazear 1999), less communication between workers (Crémer 1993), and less productive mentoring (Athey, Avery, and Zemsky 2000).
} 
Vishwanath 1996; Munshi 2003; Moretti 1999). The data allow us to examine the importance of contacts both to state migration and to the first black migration - that from rural to urban areas, including those within the south (Vickery 1977). Slaves brought into contact with free black men might be more likely to learn how to read and might be more likely to forge a new identity by abandoning their slave names. Contemporary observers wrote that former slaves fitted in Union blue were "completely metamorphosed, not only in appearance and dress, but also in character and relations" and that once in uniform "the chattel is a man" (quoted in Glatthaar 1990: 79).

\section{The Black Military Experience}

By the end of the Civil War, 186,017 men had entered the US Colored Troops, 26 percent of them from the free states, 24 percent of them from the border states or from the District of Columbia, and 50 percent of them from the Confederacy. Roughly 78 percent of age-eligible black men in the free northern states served. The comparable figures for the border states and the Confederacy were 34 and 11 percent, respectively (Metzer 1981).

Ninety-one percent of black soldiers in our random sample of companies were volunteers (as was true for white soldiers as well), 7 percent were substitutes, and 2 percent were draftees. ${ }^{2}$ Relative to whites, black soldiers were paid less. They could be promoted to corporal or sergeant, but still were paid the same as privates. Black soldiers and their officers faced greater danger than white troops if they surrendered because of uncertainty as to whether their Confederate opponents would be willing to take prisoners and, if taken prisoner, whether they would be treated as participants in a slave insurrection.

\footnotetext{
${ }^{2}$ In the border states the slaves of rebellious owners could enlist. In addition, loyal owners could volunteer their slaves for compensation of up \$300. In February of 1864 Congress authorized drafting slaves in the border states, promising slaves their freedom and their owners $\$ 100$. The draft was soon discontinued because of widespread opposition in the border states (United States. War Department. 1899, Series 3, 3:416, 418-20,861; MacGregor and Nalty 1977: 96; Blassingame 1967). While such low levels of compensation should induce slave holders in the border states to keep their best slaves, owners complained that nearby recruiting led their slaves to stop working (Blassingame 1967).
} 
Black companies' wartime experiences differed widely. Regiments formed in the last days of the war spent more time in reconstruction duty or were sent to Texas as an "Army of Observation" while Mexico was occupied by French troops. ${ }^{3}$ In our sample regiments recruited earlier and regiments recruited in the Union were more likely to have commanders with abolitionist sympathies. ${ }^{4}$ Such commanders were more likely to provide their men with formal educational opportunities (Berlin, Reidy, and Rowland 1982: 611-13). Fighting was also concentrated among relatively few regiments. During the war, black soldiers performed a disproportionate share of garrison duty and of fatigue duty, in part because there were doubts about the ability of black soldiers to fight (e.g. Berlin, Reidy, and Rowland 1998). Out of 137 black infantry regiments, 35 of them sustained almost three quarters of the entire loss in action of black troops (Hargrove 1998: 214-15).

\section{Black Company Formation and Diversity}

After the issuance of the Emancipation Proclamation in January of 1863, the War Department authorized Connecticut, Massachusetts, and Rhode Island to form black regiments. Once the Bureau of Colored Troops was established in May of 1863 to regulate and supervise the enlistment of black soldiers and the selection of officers, other northern states were authorized to recruit black regiments and at the same time the War Department expanded its efforts to recruit in the Union occupied South. The white officers who commanded the troops were also responsible for recruitment..$^{5}$ Recruitment took two forms. One method was to establish headquarters in a community and have several of the white officers comb the countryside for recruits. Another method was

\footnotetext{
${ }^{3}$ For a history of black soldiers in the Civil War see Berlin, Reidy, and Rowland (1998), Hargrove (1988), and Westwood (1992).

${ }^{4}$ It was not just slaves who were mistreated who joined the Union Army. Among the first 10 slave narratives that recounted own or a family member's service voluntary service in the Union Army (out of the first 12 narratives there are two recounting capture in the Union Army while being a servant in the Confederate Army), 6 mentioned that the master was good, 3 did not comment on the master, and 1 recounted escape to the Union Army after severe mistreatment. See the database, American Slavery: A Composite Autobiography.

${ }^{5}$ Most white officers were drawn from the regular US Army Troops. There were some black officers, but none of them were in our sample. The majority of black officers were in the Louisiana Native Guards.
} 
to send in a unit of black soldiers for a recruitment campaign. Often the families of recruits were brought within Union lines to protect them from the reprisals of slave owners. In addition, runaway slaves would cross into the border states or to Union occupied territory to enlist (Glatthaar 1990). ${ }^{6}$ Colonels whose regiments were not yet at full strength might sometimes request permission to move to different areas of the country to recruit more men. ${ }^{7}$

The white officers of the US Colored Troops included men committed to abolitionism as well as men seeking a quick promotion. In Section 4 we will show that companies with an abolitionist officer were more likely to be early enlistments, but were no more likely to be slave or free.

Why was there diversity within companies of the US Colored Troops, where diversity is measured by place of birth, slave status, and age? Some companies had few older men while others had many. Some companies were mainly composed of freemen, others of slaves, and others were mixed. Some companies drew men from the same state while others drew men from different states. The recruiters for the US Colored Troops did not have the luxury of shaping the ideal company. To maximize battlefield effort, social capital theory would suggest building homogenous units. But, a regiment that had not yet achieved full strength was not sent into battle and officers might lose their commissions if they failed to recruit in a timely manner (Glatthaar 1990). Once a company was formed it was not replenished and might fight at half strength after losing men to disease and to battlefield deaths. Since the military's objective focused on the short run goal of winning the war, rather than maximizing the present discounted expected utility of the soldiers, an externality exists. By compromising and building diverse units that were ready to fight, the military sacrificed some effort level but the men gained in later life from being exposed to this diverse environment. This plausibly exogenous cross-sectional variation in company diversity will allow us to test a variety of hypotheses below.

\footnotetext{
${ }^{6}$ While planters might flee with their most valuable slaves to Confederate lines, the most disaffected slaves may have been the more skilled slaves. In addition, as the war progressed, the number of fugitives rose (Wiley 1938; Mullin 1972).

${ }^{7}$ For example, see the Regimental Letter Book of the 10th USCT, National Archives Record Group 94.
} 


\section{Empirical Framework}

We examine the costs and benefits of diversity in military companies for black slaves and freemen who served in the Union Army. The war required soldiers to perform a relatively narrow, unskilled task. Officers had to turn their men into a disciplined fighting force that would hold its ground and not desert, go AWOL, or sleep on picket duty. We would expect that a more homogeneous company would thus be the more effective fighting unit. Officers did not need the input of their men in their decision making. ${ }^{8}$ After the war, though, soldiers may have benefited from being in a more diverse environment if they learned from their comrades. For a population in which illiteracy rates were high, learning about life in a new locality from men who had lived there would be especially valuable. In addition, men from other communities might provide direct assistance in finding jobs or housing once the war over. Slaves brought into contact with freemen might be more likely to identify with freemen and to emulate them. Freemen brought into contact with former slaves might learn by being teachers. In addition, private charitable organizations might be more likely to set up a formal schooling program in a regiment where there were many former slaves than one in which there were few, thereby benefiting freemen.

We first examine the effects of company diversity on group loyalty while in the service and then we examine the effects of company diversity on postwar outcomes. Our measure of group loyalty during the war is the first case of desertion, AWOL, or arrest. Desertion is the most serious and also the most common offense. The determination of whether a case was desertion or AWOL was made by a military court convened in the field. If a soldier was determined to have deserted, the time that he deserted was the first date that he was missing. Arrests that were not for desertion were for falling asleep while on picket duty, insubordination, drunkenness, robbery, assault, or other crimes and misdemeanors.

\footnotetext{
${ }^{8}$ Mello and Ruckes (2001) present a formal model in which the characteristics of the leader affect the impact of team diversity on the firm.
} 
We use a time-varying independent competing risk hazard model to estimate days from musterin until the first case of desertion, AWOL, or arrest. We use a competing risks framework so that we can control for such time-varying variables as morale and whether the war was over, so that we can test whether men became more committed soldiers over time, and so that we can account for censoring due to death, discharge, changing company, MIA, or becoming a POW. Note that we are assuming that the risk of desertion, AWOL, or arrest is independent of the outcomes on which we censor. Our estimated hazard, $\lambda(t)$, is

$$
\lambda(t)=\exp \left(x^{\prime} \beta\right) \lambda_{0}(t)
$$

where $\mathrm{x}$ is vector of covariates consisting of both individual and group characteristics and $\lambda_{0}$ is the baseline hazard which we assume to be Weibull. The survival function takes the form $\exp \left(-\lambda_{j} t_{j}^{p}\right)$ for subject $\mathrm{j}$, where $\mathrm{p}$ is the duration dependence parameter and can be interpreted as representing whether men who were in the war longer became more or less committed soldiers. ${ }^{9}$ The hazard ratios that we report indicate whether a one unit increase in an independent variable increases or decreases the odds of desertion, AWOL, or arrest. We account for unobserved company-level correlation by using variance correction models (Lee, Wei, and Amato 1992; Cai, Wei, and Wilcox 2000). Clustering on companies provides us with a lower bound on the standard error of company characteristics. ${ }^{10}$

We study several postwar outcomes. We examine migration across states, census regions, and city size classes between enlistment and 1900 because of the importance of migration in improving economic opportunity. We study the predictors of writing ability in the postwar period. The newly freed slaves were for the most part illiterate and most remained illiterate (Collins and Margo 2003).

\footnotetext{
${ }^{9}$ Because some men may never be disloyal, we also estimated models that accounted for individual heterogeneity. Although we found evidence of individual heterogeneity among the former slaves, the magnitude of our coefficients remained unchanged.

${ }^{10} \mathrm{We}$ also ran shared frailty models in which the frailty was specific to the company. This yielded similar results.
} 
Literacy rates for the free blacks of the north were considerably higher but still much lower than those of whites (Sacerdote, forthcoming). We also examine name changes among former slaves because among slaves who enlisted under their master's last name, a name change was arguably a way to forge a new, free identity. Slaves took their fathers' last names, even if these last names were also slave names, because free men inherited their fathers' names (Shaffer 1996: 78-9). We do not examine occupational transitions because our occupational information is poor; many of the men listed as farmers were probably laborers.

We study post-war outcomes by running probit regressions of the form

$$
\operatorname{Pr}(y=1)=\Phi(\beta X)
$$

where $\mathrm{y}$ is the indicator variable of interest (moved across state, moved across census region, in a large city, able to write, or changed last name) and $\mathrm{X}$ is a vector of individual and company characteristics. When we examine whether or not a recruit was in a large city in 1900, defined as one of the top 100 cities, we condition on enlistment in a city that in 1900 was not one of the top 100 cities. When we examine name changes we examine only those former slaves who had a name that was known to be a master's name. We cluster all standard errors on the company.

We study locational choice between enlistment and 1900 for soldiers who moved across states using a conditional logit model. This model allows us to test whether black soldiers view the same state differently depending on their initial location, on their peers, and on the geographical movements of their regiment. This 48 dimensional discrete choice model explains the probability that soldier $\mathrm{i}$ from company $\mathrm{j}$ who enlisted in state $\mathrm{m}$ chooses state 1 as a function of the attributes of state 1 , characteristics of company $\mathrm{j}$, and characteristics of enlistment state $\mathrm{m}$ and potential 
destination state 1 . That is, we estimate

$$
\operatorname{Prob}\left(S_{i j m l}\right)=\frac{\exp \left(\beta_{1} X_{l}+\beta_{2} X_{j l}+\beta_{3} X_{m l}\right)}{\sum_{l} \exp \left(\beta_{1} X_{l}+\beta_{2} X_{j l}+\beta_{3} X_{m l}\right)}
$$

The characteristics of company $\mathrm{j}\left(X_{j}\right)$ include the share of company $\mathrm{j}$ that was born in state 1 and whether company $\mathrm{j}$ toured in state $\mathrm{m}$ during the war. We interpret both of these as information measures. The characteristics of state $\mathrm{m}\left(X_{m}\right)$ consist of the state's share of the population that is black. The final set of attributes $\left(X_{l}\right)$ are a function of state of enlistment and destination state and consist of the distance between the enlistment state and the potential location and the absolute difference in latitude between the enlistment state and each possible destination. These two variables reflect transportation costs and "human capital" costs in a farm society. All else equal, migrants should be less likely to select states that are further from their enlistment state in distance and in latitude.

We estimate Equation 1 to measure the costs of diversity and Equations 2 and 3 to measure the benefits of diversity. The key explanatory variables throughout this paper are our measures of company diversity. We treat these company diversity measures as exogenous characteristics in our specifications and attach a causal interpretation to our estimated coefficients. These diversity measures depend upon the one hundred men who formed the company. The previous section provided an explanation for why companies were diverse, for reasons likely to be independent of any soldier's unobserved ability or aptitude. ${ }^{11}$ In addition, Table 1 shows that in companies where birthplace fragmentation was greater, men did not differ greatly in observable quality measures. Men in companies where birthplace fragmentation was higher were not more likely to die during the war and did not differ too much in height, their fighting experience, or their enlistment year. The fraction of companies serving under an abolitionist officer was higher in higher birthplace

\footnotetext{
${ }^{11}$ While we have differentiated officers only as abolitionists and non-abolitionists and thus we acknowledge that there is likely to be unobserved officer ability heterogeneity, we do not believe that the best officers were matched with the best units because it was not clear ex-ante who the good fighting men would be.
} 
fragmentation companies. When we examined the predictors of a company having an abolitionist officer we found that companies more likely to have an abolitionist officer were those formed earlier, those formed in the free northern states rather than the deep south, and those with higher birthplace fragmentation. We found no correlation between a company being led by an abolitionist officer and whether the regiment was a fighting regiment, the fraction of free men in the company, and birth cohort fragmentation in the company.

\section{Data}

Our data are based upon the military service and pension records of 5,673 black Union Army soldiers in 51 infantry companies. ${ }^{12}$ The military service records provide information on state of birth, age and occupation at enlistment, year and place of enlistment, and on all military service events such as death, injury, illness, desertion, arrest, AWOL, and discharge. The pension records provide information on post-bellum residence, occupation, and literacy and on name changes. We can construct a panel data set only for men who are in the pension records; however, as discussed in the Data Appendix, we do not view choice based sampling as an important issue. The data were drawn as a cluster sample, in which all of the men in the 51 companies were sampled. This enables us to create such measures of company characteristics as the percentage of free men and birthplace and cohort fragmentation. In addition we added information on the geographic movement of regiments and on officer characteristics. ${ }^{13}$ Variable definitions are provided in the Data Appendix. Table 2 shows mean company characteristics and outcomes for the entire sample and separately for slaves and freemen. We draw some comparisons with a random sample of white Union Army soldiers. ${ }^{14}$

Our sample is representative of the US Colored Troops in terms of geography and slave status.

\footnotetext{
${ }^{12}$ The sample represents roughly 2.7 percent of all blacks serving. The data were collected by a team of researchers led by Robert Fogel. Once the data are completed and cleaned, they will be available from the Center for Population Economics at the University of Chicago, http://www.cpe.uchicago.edu.

${ }^{13}$ Lee (2004) finds that wartime geographic movements affected the migration of white Union Army veterans.

${ }^{14}$ The white sample is available at http://www.cpe.uchicago.edu.
} 
Twenty-nine percent of the men in our sample were free, 28 percent percent of them were from the free states, and the remaining 72 percent were from the border and southern states. Twentytwo percent of these men died while in the service, a higher service mortality rate than that of 14 percent for white soldiers, mainly because sanitary conditions for black troops were so poor. Thirty-six percent of the men were in the 35 regiments identified by Hargrove (1988: 214-215) as having sustained the heaviest combat losses.

Roughly 9 percent of the men in our sample ever deserted, a slightly lower desertion rate than the 11 percent we find among whites. Four percent of the men in our sample were ever arrested for any reason and 1 percent were ever absent without leave. Among whites the comparable figures were 4 and 4 percent, respectively. Approximately 9 percent of all deserters in our sample were ever subsequently arrested, a figure comparable to that for whites. ${ }^{15}$

Compared to the black population as a whole our sample is more northern, of slightly higher occupational status, and more urban. Twenty-two percent of our black veterans lived in one of the top 100 cities in the United States circa 1900. Among non-veterans of the same age group in 1910 the comparable figure was 10 percent. Veterans had higher urbanization rates than non-veterans in the south as well. Among black veterans who were on the pension rolls by 1900, 41 percent of those reporting a last occupation were farmers and 11 percent were professionals, proprietors, or artisans. The comparable figures for all blacks in the same age group reporting an occupation in 1900 were 49 and 8 percent, respectively. ${ }^{16}$

Figure 1 presents a schematic diagram of the data on black soldiers. Twenty-two percent of black soldiers died during the war (over 90 percent of them from disease) and 63 percent of the war survivors or their widows are linked to the pension records. Seventy-seven percent of the

\footnotetext{
${ }^{15}$ When punishment was imposed on arrested deserters, blacks were punished more harshly. Thirteen percent of all black deserters were sentenced to hard labor or wearing a ball and chain, compared to 6 percent of white deserters. However, forty-nine percent of black deserters were not punished at all, compared to forty-four percent of white deserters. Although sample sizes are too small to determine the statistically significant predictors of harsh punishments, punishments were slightly milder in regiments with abolitionist commanders.

${ }^{16}$ Estimated from the 1910 and 1900 Integrated Public Use Census Sample.
} 
pension records are those of former slaves or widows of former slaves. By 1900, 1,515 veterans on the pension rolls were still alive and we examine migration between enlistment and 1900 for these men. We investigate postwar writing ability using information in the pension records on the writing ability of 1,728 veteran pensioners. We study name changes for the 607 former slaves whose last names were their masters' names. Information on writing literacy is available for 38 percent of pensioners and masters' names were recorded for 40 percent of the former slaves. Few observable characteristics explain non-recording. ${ }^{17}$ The regressions are estimated on somewhat fewer observations because of missing explanatory variables.

\section{Results: Combat Unit Cohesion and Company Diversity}

Black soldiers in companies with greater diversity in state of birth and in age were more likely to desert, go AWOL, or be arrested. Those who knew their fellow soldiers prior to enlisting, as proxied by having someone in the company from the same plantation, were less likely to desert, go AWOL, or be arrested (see Table 3). A standard deviation increase in birth place fragmentation increased the odds of desertion by 1.2. A standard deviation increase in cohort fragmentation increased the odds of desertion by 0.5 . The odds that a former slave was guilty of a disciplinary infraction when there was a comrade from the same plantation were one-third the odds when there was no such comrade. When we examined time until first desertion we obtained similar results. However, birthplace fragmentation was the only statistically significant diversity predictor of time until first AWOL, increasing its probability. We did not find a statistically significant relationship between birthplace or birth cohort fragmentation and time until first arrest for a cause other than desertion. We did, however, find that when a former slave was in a company with a comrade from

\footnotetext{
${ }^{17}$ The greater the number of pension applications that were generated, the more likely we are to have information on post-war writing ability. We are more likely to know writing ability for former slaves, for men injured in the war, for men who served longer, and for men who were promoted. Masters' names were less likely to be recorded for slaves who enlisted late in the war and for slaves who enlisted in the former Confederacy.
} 
the same plantation, he was less likely to be arrested.

Former slaves were more loyal to their company than free blacks. Slaves were fighting for their families' freedom, faced a lower opportunity costs of military service, and may have found their unequal pay and promotion possibilities relative to whites less galling. The odds that a former slave rather than a free man would desert, go AWOL, or be arrested were 0.606 (see Table 3). Controlling for the same set of covariates, the odds that a former slave rather than a free man would desert (results not shown) were $0.643(\hat{\sigma}=0.130$, clustered standard error). If former slaves found themselves in a company with a high fraction of free men, their group loyalty was even greater. In contrast, the group loyalty of free blacks was not significantly affected by the fraction of free men in their company. Slaves among free men may have felt a greater need to prove their worth to the freemen who were their comrades. For the former slaves being in a regiment where an officer was a known abolitionist sympathizer decreased their chances of desertion, AWOL, or arrest. In contrast, freemen's loyalty was not affected by officers' abolitionist proclivities. Both slaves and freemen who were in the war longer became more committed soldiers (our duration dependence parameter is less than one). We find some suggestive evidence that companies with a greater proportion of light-skinned soldiers were more likely to be viewed as elite. Although lightskinned soldier were as likely to desert as dark-skinned soldiers, when we included the fraction of light-skinned soldiers in the company, we obtained a statistically insignificant, but large hazard ratio of $0.306(\hat{\sigma}=0.350)$.

In earlier work (Costa and Kahn 2003), we found that company homogeneity, ideology, and morale predicted desertion, AWOL, and arrest among white soldiers. We were not able to examine whether men knew each other prior to enlistment, as we could for the black sample where we know if men were from the same plantation. Black soldiers may have been more loyal because they were more dedicated to the cause or because they knew that they and their comrades might receive no quarter on the battlefield. Compared to white soldiers black soldiers were more loyal to their 
companies controlling for individual characteristics, the share of Union victories, and such company characteristics as birthplace fragmentation (defined by state or country of birth) and company death rates (not shown). The odds that a black soldier rather than a white soldier would desert, go AWOL, or be arrested were $0.584(\hat{\sigma}=0.080)$. The odds of disloyalty for a former slave were $0.560(\hat{\sigma}=0.084)$ those of a white soldier and for a freedman $0.642(\hat{\sigma}=0.130)$ those of a white soldier. ${ }^{18}$ Whereas white soldiers who enlisted later in the war were more likely to desert, perhaps because they were less ideologically committed, there were no year of enlistment effects among black soldiers. Both whites and blacks were equally affected by company heterogeneity and by morale. The effects of birthplace fragmentation, the share of Union victories, and company death rates on desertion, AWOL, and arrest were not statistically distinguishable by race.

\section{Results: Learning During the War}

Company diversity during wartime affected postwar migration. Table 4 shows that soldiers were more likely to move across states and across census regions between enlistment and 1900 if birthplace diversity in their company was greater. A standard deviation increase in birthplace fragmentation increased the probability of a move across state by 0.16 , a 36 percent increase, and of a move across census region by 0.11 , a 38 percent increase. Soldiers were more likely to move at least $239 \mathrm{~km}$, the minimum moving distance for the most mobile 25 percent of the sample, if they were from companies where birthplace diversity was higher (results not shown). Birthplace fragmentation is not an indicator of own migratory propensities. When we included a dummy variable equal to one if the soldier was born in a state other than his state of enlistment in the state mover regression, the coefficient on birthplace fragmentation declined only to $0.470(\hat{\sigma}=.107)$. Soldiers may have either gained information on a new locality from their comrades or they may have been assisted by their former comrades in relocating after the war. Soldiers were also more likely to

\footnotetext{
${ }^{18}$ The standard errors are clustered on the company.
} 
move to a new census region if they had traveled through a new census region during the war, perhaps because they gained new information during their travels (see Table 4). Traveling to a new census region increased the probability of a move across census regions by 0.13 . The results for former slaves and freemen (not shown) were similar. Among soldiers who had not enlisted in a large city during the war, movement to a large city was predicted by travel to a city during the war and by the fraction of men in the company who had enlisted in a large city (see Table 4). Travel with the regiment to a large city increased the probability of a move to a large city by 0.09 , a 30 percent increase. A standard deviation increase in the fraction of the company enlisting in a large city increased the probability of moving to a large city by 0.04 , a 12 percent increase. Company state of birth fragmentation did not predict a move to large city, probably because it is a poor indicator of diversity in size of city of residence. Soldiers in companies where birth cohort fragmentation was higher were likely to move to a city.

Push factors may also have played a role in soldiers' migration decisions. Former black soldiers and their families were targets of mob anger in the south, because in the words of one former black chaplain he was "looked upon as a runaway 'nigger' who has been fighting against his old master and now returns full of impudent notions of a freeman" (quoted in Glatthaar 1990: 252). Matters may only have worsened with the removal of Union troops from the south in 1877 . We tried to test for the importance of "push" factors by including in our migration probits the Republican share of the presidential vote in the state that the soldier enlisted in as a proxy for black enfranchisement. In the South the Republican party was the party of Reconstruction. We found that among men who enlisted in the former Confederacy, men who enlisted in states where Garfield received a larger share of the vote in 1880 were less likely to move across state between enlistment and 1900. The derivative of the coefficient on Garfield's share of the vote was -0.036 ( $\hat{\sigma}=0.012$, robust clustered standard errors). When we used Hayes' share of the vote in 1876 instead the derivative of the coefficient was -0.030 ( $\hat{\sigma}=0.017$, robust clustered standard errors). These political variables were 
insignificant when we looked at the former Union states.

What determined what state a veteran moved to? Table 5 shows that, conditional on moving across states between enlistment and 1900 (as was true for 891 men), veterans were more likely to move to a state where they had traveled during the war or where a large fraction of the men in the company were from. A veteran's odds of moving to a state was 1.4 times higher if the regiment passed through that state than if it had not. An increase of 0.1 in the fraction of men in the company from a particular state increased the odds that a veteran would move to that state by 0.3 . A higher black population share increased the odds of a veteran moving there, but not statistically significantly so. The further away a state and the greater its latitude from the state of enlistment, the less likely a veteran was to move there. When we controlled for the percent of the state's population in manufacturing we obtained a negative and statistically significant coefficient - the fraction of the state's black population and the share of the population in manufacturing were negatively correlated.

Table 5 also shows that the effect of the fraction of men in the company from a state on the probability of moving to that state was smaller if the veteran could write, perhaps because veterans who could write were less dependent upon their comrades for information about localities. For the illiterate an increase of 0.1 in the fraction of men in the company from a particular state raised the odds of moving to that state by 0.32 . In contrast, for the literate such an increase in the fraction of men in the company from a particular state raised the odds of their moving to that state by only 0.29. Note that when the fraction of blacks in the state is interacted with writing ability, it becomes a statistically significant predictor of veteran's odds of moving to that state. An increase of 0.1 in the fraction of blacks in the state increased the odds that an illiterate veteran would move there by 0.29 and increased the odds that a literate veteran would move there by 0.28 . Once again, networks of friends may have been more important for the illiterate. In contrast to the literacy results, there were no differential effects by slave status. 
The former slaves were more likely to be able to write after the war if they were in a company with a large fraction of free men (see Table 6). A standard deviation increase in the fraction of the company that was free increased the probability that a veteran could write by 0.28 , an increase of 108 percent. This is probably an underestimate of the true effect; if charitable organizations focused their efforts on slave units, we would expect that slaves would benefit from being with other slaves. Because free men were more likely to be able to write, for slaves comrades may have been a valuable educational resource. The greater the number of days spent in the army, the more likely the former slaves were to be literate. An additional hundred days spent in the army increased the probability that a veteran could write by $0.21 .{ }^{19}$ Whether or not a commanding officer had abolitionist tendencies did not matter. ${ }^{20}$ In contrast, for the free men, having an abolitionist officer was a positive predictor of postbellum writing ability and a large fraction of freemen in the company was a negative predictor of writing ability. ${ }^{21}$ Perhaps literate freemen were more likely to help illiterate slaves than illiterate freemen. For the freemen greater age diversity was also a negative predictor of post-war writing ability.

An observable signal of forging a new identity and leaving one's slave experience behind is to change your name. Recent economic research has examined the causes and consequences of distinctively black names in the present (see Fryer and Levitt 2004 and Bertrand and Mullainathan 2004). Building on this research, we examine the causes of name changes for our ex-slave sample. A larger share of free men in the company encouraged the former slaves to abandon their slave names. When we examined the 576 former slaves who had a last name that was the name of their master and for whom we had fairly complete records, we found that 32 percent of them changed

\footnotetext{
${ }^{19}$ Some companies served fewer days than the regular 3 year term because they formed late and were disbanded when the war ended.

${ }^{20}$ Relative to men who did not serve there some modest schooling effects of military service. Twenty-eight percent of African-Americans veterans living in the south in 1910 were able to write compared to 25 percent of non-veterans of the same age group. (Estimated from the 1910 Integrated Public Use Census sample.)

${ }^{21}$ While it is possible that freemen in slave units were in the right tail of the ability distribution, we find no evidence that freemen in slave units were more likely to be promoted than freemen in free units.
} 
their last name and that in a probit regression the derivative of the coefficient on the fraction of free men in the company was $0.224(\hat{\sigma}=0.102$, where the standard error is clustered on the company $){ }^{22}$ For the small set of men whose fathers' names were listed in the pension records, we were able to determine that most men who changed their last names changed them to their fathers' last names. Name changes were not statistically significant predictors of either postwar migration or writing ability. However, the magnitude of the coefficients suggested that former slaves who had rejected their masters' last names were more likely to migrate across states and were more likely to write.

\section{Conclusion}

For a former slave, a dramatic observable life change would be abandoning one's slave name, a change in residence, and becoming literate. Was Civil War service a catalyst for these changes? Because each of the 51 companies in our data set experienced a different set of peers and because each of the 39 regiments in our data set experienced a different set of leaders and traveled to different places, we can test how different war experiences changed the lives of ex-slaves and freemen. We find that in the short run, the combat unit benefited from homogeneity as this social capital minimized shirking but in the long run the both slaves' and freemen's human capital and information was best served by fighting in heterogeneous companies. ${ }^{23}$ Slaves who fought with freemen were more likely to be literate after the war, perhaps because freemen served as teachers. Freemen who fought with slaves were also more likely to be literate either because they learned in their role as teachers or because they benefited from educational programs set up for slaves.

Participation in the Civil War may have both magnified the initial differences between slaves and freemen and created the necessary conditions that allowed the descendants of slaves to catch

\footnotetext{
${ }^{22}$ We also found that 17 percent of free men changed their names. However, company characteristics did not predict name changes among free men.

${ }^{23}$ While we have documented the benefits of participating in a heterogeneous unit, we cannot construct the counterfactual of how a black man's life choices would evolve if he had not served in the military. We do not have a control group of men who were close to being drafted but did not serve.
} 
up to the descendants of free men. It took two generations for the descendants of slaves to catch up to the descendants of free black men and women in literacy, occupation, and children's school attendance (Sacerdote, forthcoming). The majority of northern, black freemen served whereas only a fraction of blacks in the former slave states served. The freemen therefore disproportionately benefited from knowledge of migration opportunities learned from comrades or from travel and from educational programs set up by abolitionist officers. However, the war exposed some former slaves to new social interactions, allowing them to learn of migration opportunities, to learn how to write, and to adopt a freeman's identity. Slaves who had served in the Union Army in turn may then have paved the way for other ex-slaves, by helping them to adjust to freedom and to migrate from rural to urban areas. While the positive relationship between company diversity and desertion, AWOL, and arrest suggests that neither individual soldiers nor the army liked diversity, the post-war benefits of company diversity may have been extremely high.

\section{Data Appendix}

\section{Pension Records}

What determined entry on the pension rolls we use to obtain information about postwar outcomes? Both white and black veterans were eligible for a pension for war-related injuries. In 1890 pensions began to be paid for any disability, regardless of its relation to the war and by 1907 old age was recognized by Congress as a disability. Given the high rates of discrimination against blacks around the turn of the century, the pension program was relatively non-discriminatory. Among all men who identified themselves as Union veterans in the 1910 census we were able to find 86 percent of the white veterans and 79 percent of the black veterans in the pension records. Although blacks were less successful than whites in their original pension applications and in applications for increases (Blanck and Song 2004), even when an application was rejected, information about 
geographic residence, writing ability, and name changes was recorded. Soldiers who survived the war were less likely to have a pension record if they had ever deserted (deserters who never returned to fight were ineligible), if they had never been injured in the war, if they were not from a fighting regiment, if they had never been promoted, if they were born in the Confederacy, if they were freemen, and if they were light-skinned.

\section{Dependent Variables}

We examine time until first desertion, arrest, or AWOL among men in the service. For men on the pension rolls we use several dependent variables. We examine moves between state of enlistment and 1900 using a dummy variable equal to one if the veteran ever moved across states and a dummy variable equal to one if the veteran ever moved across census regions. We investigate urbanization between enlistment and 1900 by using a dummy variable equal to one if a veteran lived in city of at least 38,300 in 1900 (one of the top 100 cities) and condition on the recruit enlisting in a city that in 1900 was not one of the top 100 cities. We check what state a veteran moved to, conditional on his being a mover, using an indicator variable for all 48 states (or territories). We investigate the determinants of a veteran's writing ability using an indicator variable equal to one if the veteran could write. This variable is not a good indicator of overall literacy rates because information on writing literacy is not available for everyone in the sample. We also created a variable indicating whether or not a soldier changed his name. We examine name changes only among former slaves who had a name that was a master's name.

\section{Independent, Individual Variables}

Our individual control variables are age at enlistment; dummy variables indicating occupation at enlistment (farmer; professional, proprietor, or artisan; servant; laborer; and, unknown); a dummy equal to one if the recruit was born in the Confederacy; a dummy variable equal to one if the recruit was paid a bounty upon enlistment and a dummy variable equal to one if the recruit was owed a bounty; dummy variables indicating year of muster or enlistment; a dummy equal to one if the 
recruit was light-skinned; a dummy equal to one if the recruit was wounded in the war; the number of days served until discharge; a dummy equal to one if the soldier was ever promoted to corporal or sergeant; and, a dummy variable indicating whether or not the recruit was a slave. When slave status was not given (true for 64 percent of the sample), it was inferred from state of enlistment, e.g. all men enlisting in slave states were assumed to be slaves and vice-versa. ${ }^{24}$ When we examine post-war migration we also control for whether or not the recruit could write.

\section{Company Characteristics}

1. Birth place fragmentation. We calculated, by company, the fraction of individuals born in each US state. Our birthplace fragmentation index, $f_{i}$, is then

$$
f_{i}=1-\sum_{k} s_{k i}^{2}
$$

where $k$ represents the categories and where $s_{k i}$ is the share of men born in place $k$ in company $i$.

2. Cohort fragmentation. We calculated, by company, the fraction of individual born in each 5 year birth cohort. Our cohort fragmentation index is then calculated the same way as our birthplace fragmentation index.

3. Fraction of company free. The fraction of the company consisting of free men.

4. Fraction of the company dying. The fraction of the company dying while in the service. A single variable when used as a control for post-war experiences.

5. Fraction promoted. Fraction of the company promoted to corporal or sergeant.

6. Abolitionist officer. Dummy equal to one if any of the regiment's officers were known to be

\footnotetext{
${ }^{24}$ Fogel and Engerman (1984: 37) estimate that only 6 percent of blacks in the south were free. The free blacks of the North were primarily the descendants of colonial era slaves (Hodges 1997).
} 
friendly to the abolitionist cause. Information on who the regiment's officers with ranks of colonel, lieutenant-colonel, or major were was obtained from Dyer (1908) and from U.S. Adjutant General's Office (1867). Information on these officers' sentiments was obtained from U.S. War Department (1880-1901), Glatthaar (1990), Hargrove (1988), Westwood (1992), Boatner (1959), and Hubbell and Geary (1995).

7. Same plantation. Dummy equal to one if the slaves were ever on the same plantation, as indicated by the owners' names.

8. Fighting regiment. Dummy equal to one if the regiment sustained heavy losses, as indicated in Hargrove (1988: 214-15).

9. Regiment traveled to new region. Dummy equal to one if the regiment ever moved to a new census region from that of enlistment. Compiled from Dyer (1908).

10. Regiment traveled to a city. Dummy equal to one if the regiment ever traveled to a city (other than that of enlistment). Compiled from Dyer (1908).

\section{Other Variables}

In our hazard models we also control for whether or not the nation was still at war with a timevarying dummy variable which varies every half year. We also control for the fraction of Union victories through a time-varying variable that indicates for each half year that the recruit was in service the fraction of major Union victories to all major battles in that half year. This variable takes the value 0 if there were no major battles.

\section{References}

[1] Acemoglu, Daron, David H. Autor, and David Lyle. 2004. "Women, War, and Wages: The Effect of Female Labor Supply on the Wage Structure at Midcentury." Journal of Political Economy. 112(3): 497-551. 
[2] Alesina, Alberto and Eliana La Ferrara. 2004. "Ethnic Diversity and Economic Performance." NBER Working Paper No. 10313, February.

[3] Angrist, Joshua D. 1990. "Lifetime Earnings and the Vietnam Era Draft Lottery: Evidence from Social Security Administrative Records." American Economic Review. 80(3): 313-36.

[4] Angrist, Joshua D. and Alan B. Krueger. 1994. "Why Do World War II Veterans Earn More Than Nonveterans?” Journal of Labor Economics. 12(1): 74-97.

[5] Athey, Susan, Christopher Avery, and Peter Zemsky. 2000. "Mentoring and Diversity." The American Economic Review. 90(4): 765-86.

[6] Blassingame, John W. 1967. "The recruitment of colored troops in Kentucky, Maryland, and Missouri: 1863-1865." The Historian. 29(4): 533-45.

[7] Boatner, Mark M. 1959. The Civil War Dictionary. New York: D. McKay co.

[8] Berlin, Ira, Joseph P. Reidy, and Leslie S. Rowland, Eds. 1982. The Black Military Experience. Series II in Freedom: A Documentary History of Emancipation, 1861-1867. Cambridge: Cambridge University Press.

[9] Berlin, Ira, Joseph P. Reidy, and Leslie S. Rowland, Eds. 1998. Freedom's Soldiers: The Black Military Experience in the Civil War. Cambridge-New York: Cambridge University Press.

[10] Bertrand, Marianne and Sendhil Mullainathan. 2004. "Are Emily and Greg More Employable than Lakisha or Jamal? A Field Experiment on Labor Market Discrimination." American Economic Review. 94(4): 991-1013.

[11] Blanck, Peter and Chen Song. 2004. "Civil War Pensions for Union Army Veterans: Race and Disability." Paper presented at the NBER Cohort Studies and EI Meeting, April 2004.

[12] Bowen, William G. and Derek Bok. 1998. The Shape of the River: Long-Term Consequences of Race in College and University Admissions. Princeton, NJ: Princeton University Press.

[13] Cai, T., L.J. Wei, and M. Wilcox. 2000. "Semiparametric Regression Analysis for Clustered Failure Time Data.” Biometrika. 87: 867-78.

[14] Carillo, Juan D. and Denis Gromb. 2002. "Cultural Inertia and Uniformity in Organizations." CEPR Discussion Paper 3613, October.

[15] Carrington, William J., Enrica Detragiache, and Tara Vishwanath. 1996. "Migration with Endogeneous Moving Costs.” American Economic Review. 86(4): 909-30.

[16] Collins, William J. and Robert A. Margo. 2003. "Historical Perspectives on Racial Differences in Schooling in the United States.” NBER Working Paper No. 9770, June. 
[17] Costa, Dora L. and Matthew E. Kahn. 2003. "Cowards and Heroes: Group Loyalty in the American Civil War.” Quarterly Journal of Economics. 118(2): 519-48.

[18] Crémer, Jacques. 1993. "Corporate Culture and Shared Knowledge.” Industrial and Corporate Change. 2: 351-86.

[19] Durlauf, Steven N. and Marcel Fafchamps. 2004. "Social Capital.” NBER Working Paper No. 10485, May.

[20] Dyer, Frederick H. 1908. A Compendium of the War of the Rebellion. Des Moines, IA: The Dyer Pub. Co.

[21] Fershtman, Chaim, Hans K. Kvidel, and Yoram Weiss. 2003. "Cultural Diversity, Status Concerns, and the Organization of Work." CEPR Discussion Paper 3982, July.

[22] Fogel, Robert W. and Stanley L. Engerman. 1984. Time on the Cross: The Economics of American Negro Slavery. Boston-London: University Press of America (originally published, Boston: Little, Brown, and Company, 1974).

[23] Fryer, Roland G. and Steven D. Levitt. 2004. "The Causes and Consequences of Distinctively Black Names." Quarterly Journal of Economics. 119(3): 767-805.

[24] Glaeser, Edward L., Andrei Shleifer, Hedi D. Kallal, and Jose A. Scheinkman. 1992. "Growth in Cities." Journal of Political Economy. 100(6): 1126-52.

[25] Glatthaar, Joseph T. 1990. Forged in Battle: The Civil War Alliance of Black Soldiers and White Officers. New York-London: The Free Press.

[26] Guryan, Jonathan. 2004."Desegregation and Black Dropout Rates.” American Economic Review. 94(4): 919-43.

[27] Hargrove, Hondon B. 1988. Black Union Soldiers in the Civil War. Jefferson, NC and London: McFarland and Company, Inc.

[28] Hodges, Graham Russell. 1997.1997. Slavery and Freedom in the Rural North. Madison, WI: Madison House Publishers.

[29] Hubbell, John and James W. Geary. 1995. Biographical Dictionary of the Union: Northern Leaders of the Civil War. Westport, CT: Greenwood Press.

[30] Lazear, Edward P. 1999. “Culture and Language.” The Journal of Political Economy. 107(6, Part 2): S95-S126.

[31] Lee, Chulhee. 2004. "Health, Military Service, and Economic Mobility of Union Army Veterans.” Paper presented at the NBER Cohort Studies and EI Meeting, April 2004. 
[32] Lee, W.W., L.J. Wei, and D.A. Amato. 1992. "Cox-type Regression Analysis for Large Numbers of Small Groups of Correlated Failure Time Observations." In J.P. Klein and P.K. Goel, Eds., Survival Analysis: State of the Art. Dordrecht, Netherlands: Kluwer.

[33] MacGregor, Morris and Nalty, Bernard C. 1977. Blacks in the United States Armed Forces: Basic Documents. Vol 2. Wilmington, DE: Scholarly Resources.

[34] Mello, Antonio S. and Martin Ruckes. 2001. "Diversity in Organizations." CEPR Discussion Paper 2673, January.

[35] Metzer, Jacob. 1981. "The Records of the U.S. Colored Troops as Historical Source: An Exploratory Examination." Historical Methods. 14: 123-32.

[36] Moretti, Enrico. 1999. "Social Migrations and Networks: Italy 1889-1913.” International Migration Review.

[37] Mullin, Gerald W. 1972. Flight and Rebellion: Slave Resistance in Eighteenth-Century Virginia. New York: Oxford University Press.

[38] Munshi, Kaivan. 2003. "Networks in the Modern Economy: Mexican Migrants in the U.S. Labor Market.” Quarterly Journal of Economics. 118(2): 549-99.

[39] Sacerdote, Bruce. Forthcoming. "Slavery and the Inter-generational Transmission of Human Capital." Review of Economics and Statistics.

[40] Shaffer, Donald Robert. 1996. "Marching On: African-American Civil War Veterans in Postbellum America, 1865-1951.” Unpublished Phd Dissertation. University of Maryland at College Park.

[41] United States. Adjutant General's Office. Official Army Register of the Volunteer Force for the Years 1861, 1862, 1863, 1864, 1865. Part VIII. Published by order of the Secretary of War, Washington, DC. Reprinted 1987. Gaithersburg, MD: Ron R. Van Sickle Military Books.

[42] United States. War Department. 1880-1901. The War of the Rebellion: A Compilation of the Official Records of the Union And Confederate Armies. Washington DC: Government Printing. Office.

http://moa.cit.cornell.edu/moa/browse.monographs/waro.html.

[43] Vickery, William Edward. 1977. The Economics of the Negro Migration, 1900-1960. New York: Arno Press.

[44] Westwood, Howard C. 1992. Black Troops, White Commanders, and Freedmen During the Civil War. Carbondale and Edwardsville, IL: Southern Illinois University Press.

[45] Wiley, Bell Irvin. 1938. Southern Negroes, 1861-1865. New Haven, CT: Yale University Press. 
Table 1: Mean Characteristics of High and Low Birth Place Diversity Companies

\begin{tabular}{lrr}
\hline \hline & Low Diversity & High Diversity \\
\hline Died in war & 0.218 & 0.232 \\
Height (cm) & 168.517 & 169.283 \\
Enlisted in 1863 & 0.348 & 0.402 \\
Enlisted in 1864 & 0.513 & 0.474 \\
Enlisted in 1865 or later & 0.139 & 0.124 \\
In fighting regiment & 0.388 & 0.362 \\
Abolitionist officer & 0.136 & 0.415 \\
\hline
\end{tabular}

Low diversity companies are companies where birthplace fragmentation is below the median and high diversity companies are companies where birthplace fragmentation is above the median. See the Data Appendix for a definition of birthplace fragmentation. 
Table 2: Mean Company Characteristics and Outcomes for Slaves and Freemen

\begin{tabular}{lrrr}
\hline \hline & All & Slaves & Freemen \\
\hline Mean Company Characteristics & & & \\
Birth place fragmentation & 0.565 & 0.555 & 0.586 \\
& $(0.240)$ & $(0.238)$ & $(0.243)$ \\
Cohort fragmentation & 0.752 & 0.759 & 0.738 \\
& $(0.062)$ & $(0.066)$ & $(0.051)$ \\
Fraction of company that free & 0.293 & 0.142 & 0.614 \\
Fraction of company enlisting in a large city & 0.253 & 0.197 & 0.371 \\
Fraction with abolitionist officer & 0.282 & 0.233 & 0.384 \\
Fraction with fellow soldier from same plantation & & 0.049 & \\
Fraction traveled to new census region while in service & 0.755 & 0.712 & 0.846 \\
Fraction traveled to a city while in service & 0.734 & 0.687 & 0.864 \\
Military Service Outcomes & & & \\
Ever deserted & 8.6 & 8.7 & 8.6 \\
Ever AWOL & 4.1 & 3.7 & 5.0 \\
Ever arrested & 1.4 & 1.6 & 1.2 \\
Postwar Outcomes & & & \\
\% State mover between enlistment and 1900 & & & \\
\% Census region mover between enlistment and 1900 & 29.2 & 29.5 & 28.3 \\
\% Moved to a large city and did not enlist in a large city & 27.2 & 26.8 & 29.5 \\
\% Writes & 25.7 & 23.7 & 33.8 \\
\% Changed name if slave with master's last name & & 32.3 & \\
\hline \hline
\end{tabular}

Standard errors are in parentheses. A large city is defined as one that in 1900 was one of the top 100 cities in the United States. Writing ability is not known for 4 percent of the sample who were alive and on the pension rolls by 1900. 
Table 3: Competing Risk Hazard Model of Waiting Time until Desertion, AWOL, or Arrest

\begin{tabular}{lrrr}
\hline \hline & All & Slaves & Freeman \\
& Hazard & Hazard & Ratio \\
Ratio & \multicolumn{1}{c}{$\begin{array}{c}\text { Ratio } \\
\text { Rard }\end{array}$} \\
\hline Dummy=1 if slave & $0.606^{\ddagger}$ & & \\
& $(0.098)$ & & \\
Birth place fragmentation & $4.984^{\ddagger}$ & $3.453^{\dagger}$ & $3.274^{\dagger}$ \\
& $(2.180)$ & $(1.802)$ & $(1.941)$ \\
Cohort fragmentation & $8.525^{*}$ & 1.928 & 27.723 \\
& $(11.072)$ & $(2.346)$ & $(100.291)$ \\
Fraction of company that was free & $0.467^{\dagger}$ & $0.189^{\ddagger}$ & 1.159 \\
& $(0.149)$ & $(0.095)$ & $(0.614)$ \\
Dummy=1 if abolitionist officer & 0.776 & $0.693^{\dagger}$ & 1.061 \\
& $(0.146)$ & $(0.108)$ & $(0.246)$ \\
Dummy=1 if fellow soldier from same plantation & & $0.358^{*}$ & \\
& & $(0.191)$ & \\
Duration dependence parameter & $0.714^{\ddagger}$ & $0.728^{\ddagger}$ & $0.711^{\ddagger}$ \\
& $(0.038)$ & $(0.040)$ & $(0.097)$ \\
$\chi^{2}(20) / \chi^{2}(19)$ & 792.62 & 562.80 & 426.88 \\
\hline \hline
\end{tabular}

5,182 subjects, 3,614 slave and 1,568 free. Estimated from a competing risk hazard model. Days until first desertion, arrest, or AWOL are measured from first mustering in. The first instance of either is an event. Standard errors, clustered on the company, are in parentheses. The symbols $*, \dagger$, and $\ddagger$ indicate that the coefficient is significantly different from 1 at the 10,5, and 1 percent level, respectively. Significance of all coefficients is for equality of all coefficients to one. Men who died, became POWs, were discharged, were missing in action, or changed companies before the first desertion, arrest, or AWOL are treated as censored. Additional covariates are dummies for year of enlistment, dummies for occupation at enlistment, dummies for bounty paid and bounty due, a dummy for light-skinned, a dummy if born in a Confederate state, age, a dummy if the nation was at war, a dummy if the regiment was a fighting regiment, and the fraction of Union victories. 
Table 4: Determinants of the Postwar Probability of Moving Across State, Region, or City

\begin{tabular}{|c|c|c|c|}
\hline & \multicolumn{3}{|c|}{ Moves Across } \\
\hline & $\begin{array}{l}\text { State } \\
\frac{\partial P}{\partial x}\end{array}$ & $\begin{array}{c}\text { Region } \\
\frac{\partial P}{\partial x}\end{array}$ & $\begin{array}{c}\text { City Size } \\
\frac{\partial P}{\partial x}\end{array}$ \\
\hline \multirow[t]{2}{*}{ Dummy $=1$ if slave } & -0.014 & -0.019 & $0.071^{*}$ \\
\hline & $(0.048)$ & $(0.052)$ & $(0.036)$ \\
\hline \multirow[t]{2}{*}{ Birth place fragmentation } & $0.664^{\ddagger}$ & $0.465^{\ddagger}$ & 0.092 \\
\hline & $(0.104)$ & $(0.110)$ & $(0.079)$ \\
\hline \multirow[t]{2}{*}{ Cohort fragmentation } & -0.088 & 0.193 & $-0.817^{\dagger}$ \\
\hline & $(0.472)$ & $(0.418)$ & $(0.349)$ \\
\hline \multirow[t]{2}{*}{ Fraction of the company that was free } & -0.123 & $-0.192^{\dagger}$ & $0.149^{\dagger}$ \\
\hline & $(0.084)$ & $(0.086)$ & $(0.071)$ \\
\hline \multirow[t]{2}{*}{ Fraction of the company enlisting in a large city } & & & $0.172^{\dagger}$ \\
\hline & & & $(0.088)$ \\
\hline \multirow[t]{2}{*}{ Dummy $=1$ if abolitionist officer } & -0.040 & -0.015 & 0.065 \\
\hline & $(0.059)$ & $(0.053)$ & $(0.043)$ \\
\hline \multirow[t]{2}{*}{ Dummy $=1$ if regiment traveled to new region } & 0.039 & $0.134^{\dagger}$ & \\
\hline & $(0.063)$ & $(0.051)$ & \\
\hline \multirow[t]{2}{*}{ Dummy $=1$ if regiment traveled to city } & & & $0.092^{*}$ \\
\hline & & & $(0.051)$ \\
\hline Pseudo $R^{2}$ & 0.085 & 0.092 & 0.100 \\
\hline
\end{tabular}

Estimated from a probit model. Moves across city size are moves to a city that in 1900 was one of the top 100 cities, conditional on enlisting in a city that in 1900 was not one of the top 100 cities. Standard errors, clustered on the company, are in parentheses. The symbols $*, \dagger$, and $\ddagger$ indicate that the coefficient is significantly different from 0 at the 10, 5 , and 1 percent level, respectively. Additional covariates are dummies for year of enlistment, dummies for occupation at enlistment, dummies for birth cohort, a dummy for light-skinned, a dummy if born in a Confederate state, the logarithm of the number of days served, a dummy if the regiment was a fighting regiment, a dummy if individual was promoted, the fraction of the company that was promoted, the fraction of the company that died in service, a dummy equal to one if the recruit was injured during the war, and dummies indicating writing ability, including unknown. The first two regressions contain 1498 observations and the last regression contains 1163 observations. 
Table 5: Determinants of State Migrant Locational Choice

\begin{tabular}{lrrrr}
\hline \hline & $\begin{array}{r}\text { Coef- } \\
\text { icient }\end{array}$ & $\begin{array}{r}\text { Odds } \\
\text { Ratio }\end{array}$ & $\begin{array}{r}\text { Coef- } \\
\text { icient }\end{array}$ & \multicolumn{1}{c}{ Odds } \\
& Ratio \\
\hline Dummy=1 if regiment was there & $0.341^{\ddagger}$ & $1.406^{\ddagger}$ & 0.235 & 1.264 \\
& $(0.110)$ & $(0.155)$ & $(0.146)$ & $(0.185)$ \\
Fraction of men in company from that state & $1.131^{\ddagger}$ & $3.098^{\ddagger}$ & $1.159^{\ddagger}$ & $3.187^{\ddagger}$ \\
& $(0.206)$ & $(0.637)$ & $(0.277)$ & $(0.884)$ \\
Fraction of state population that was black & 0.200 & 1.221 & $0.873^{\ddagger}$ & $2.395^{\ddagger}$ \\
& $(0.197)$ & $(0.240)$ & $(0.251)$ & $(0.600)$ \\
Distance from enlistment state (miles/100) & $-0.170^{\ddagger}$ & $0.844^{\ddagger}$ & $-0.177^{\ddagger}$ & $0.838^{\ddagger}$ \\
& $(0.013)$ & $(0.011)$ & $(0.019)$ & $(0.016)$ \\
Latitude difference from enlistment state (minutes) $)$ & $-0.072^{\ddagger}$ & $0.931^{\ddagger}$ & $-0.066^{\ddagger}$ & $0.937^{\ddagger}$ \\
& $(0.018)$ & $(0.017)$ & $(0.025)$ & $(0.023)$ \\
Writes $\times$ Regiment was there & & & 0.423 & 1.526 \\
& & & $(0.290)$ & $(0.442)$ \\
Writes $\times$ Fraction men from state & & & $-1.338^{\dagger}$ & $0.262^{\dagger}$ \\
Writes $\times$ Fraction of black population & & & $(0.574)$ & $(0.151)$ \\
Writes $\times$ Distance & & & $-2.892^{\ddagger}$ & $0.055^{\ddagger}$ \\
Writes $\times$ Latitude & & & $-0.558)$ & $(0.031)$ \\
& & & $(0.001$ & 0.993 \\
Pseudo $R^{2}$ & & & -0.033 & $(0.031)$ \\
\hline \hline
\end{tabular}

Coefficients and odds ratios are from a conditional logit model (Equation 3 in the text). Characteristics are the characteristics of the potential location (state). The soldier decides which state to move to based upon its characteristics, conditional on moving to a state that is not his enlistment state. Each observation, $s_{i j}$, is person i's potential choice of state $\mathrm{j}$. Robust standard errors, clustered on the individual, are in parentheses. The symbols $*, \dagger$, and $\ddagger$ indicate that the coefficient is significantly different from 0 at the 10,5 , and 1 percent level, respectively. 34,710 observations in the first regression and 27,534 observations in the second regression (individuals for whom writing ability is unknown were excluded). 
Table 6: Determinants of Postwar Writing Ability

\begin{tabular}{|c|c|c|c|}
\hline & $\begin{array}{l}\text { All } \\
\frac{\partial P}{\partial x} \\
\end{array}$ & $\begin{array}{c}\text { Slaves } \\
\frac{\partial P}{\partial x} \\
\end{array}$ & $\begin{array}{c}\text { Freemen } \\
\frac{\partial P}{\partial x} \\
\end{array}$ \\
\hline Dummy $=1$ if slave & $\begin{array}{l}-0.081^{\dagger} \\
(0.040)\end{array}$ & & \\
\hline Birth place fragmentation & $\begin{array}{r}-0.048 \\
(0.059)\end{array}$ & $\begin{array}{r}-0.034 \\
(0.065)\end{array}$ & $\begin{array}{r}-0.041 \\
(0.128)\end{array}$ \\
\hline Cohort fragmentation & $\begin{array}{r}-0.317 \\
(0.210)\end{array}$ & $\begin{array}{r}-0.128 \\
(0.283)\end{array}$ & $\begin{array}{c}-1.266^{\ddagger} \\
(0.412)\end{array}$ \\
\hline Fraction of the company that free & $\begin{array}{r}0.050 \\
(0.042)\end{array}$ & $\begin{array}{c}0.081^{*} \\
(0.047)\end{array}$ & $\begin{array}{c}-0.438^{\ddagger} \\
(0.176)\end{array}$ \\
\hline Dummy $=1$ if abolitionist officer & $\begin{array}{r}0.039 \\
(0.031)\end{array}$ & $\begin{array}{r}0.012 \\
(0.040)\end{array}$ & $\begin{array}{c}0.122^{\dagger} \\
(0.056)\end{array}$ \\
\hline $\log ($ number of days served) & $\begin{array}{c}0.044^{\dagger} \\
(0.021)\end{array}$ & $\begin{array}{r}0.052^{\dagger} \\
(0.023)\end{array}$ & $\begin{array}{r}0.045 \\
(0.047)\end{array}$ \\
\hline Pseudo $R^{2}$ & 0.061 & 0.049 & 0.151 \\
\hline
\end{tabular}

Estimated from a probit model. Standard errors, clustered on the company, are in parentheses. The symbols $*, \dagger$, and $\ddagger$ indicate that the coefficient is significantly different from 0 at the 10,5 , and 1 percent level, respectively. Additional covariates are dummies for year of enlistment, dummies for occupation at enlistment, dummies for birth cohort, a dummy for light-skinned, the logarithm of the number of days served, a dummy if the regiment was a fighting regiment, a dummy if individual was promoted, and a dummy equal to one if the recruit was injured during the war. 1,643 observations, 1,315 slaves and 328 freemen. 
Figure 1: Schematic of Data

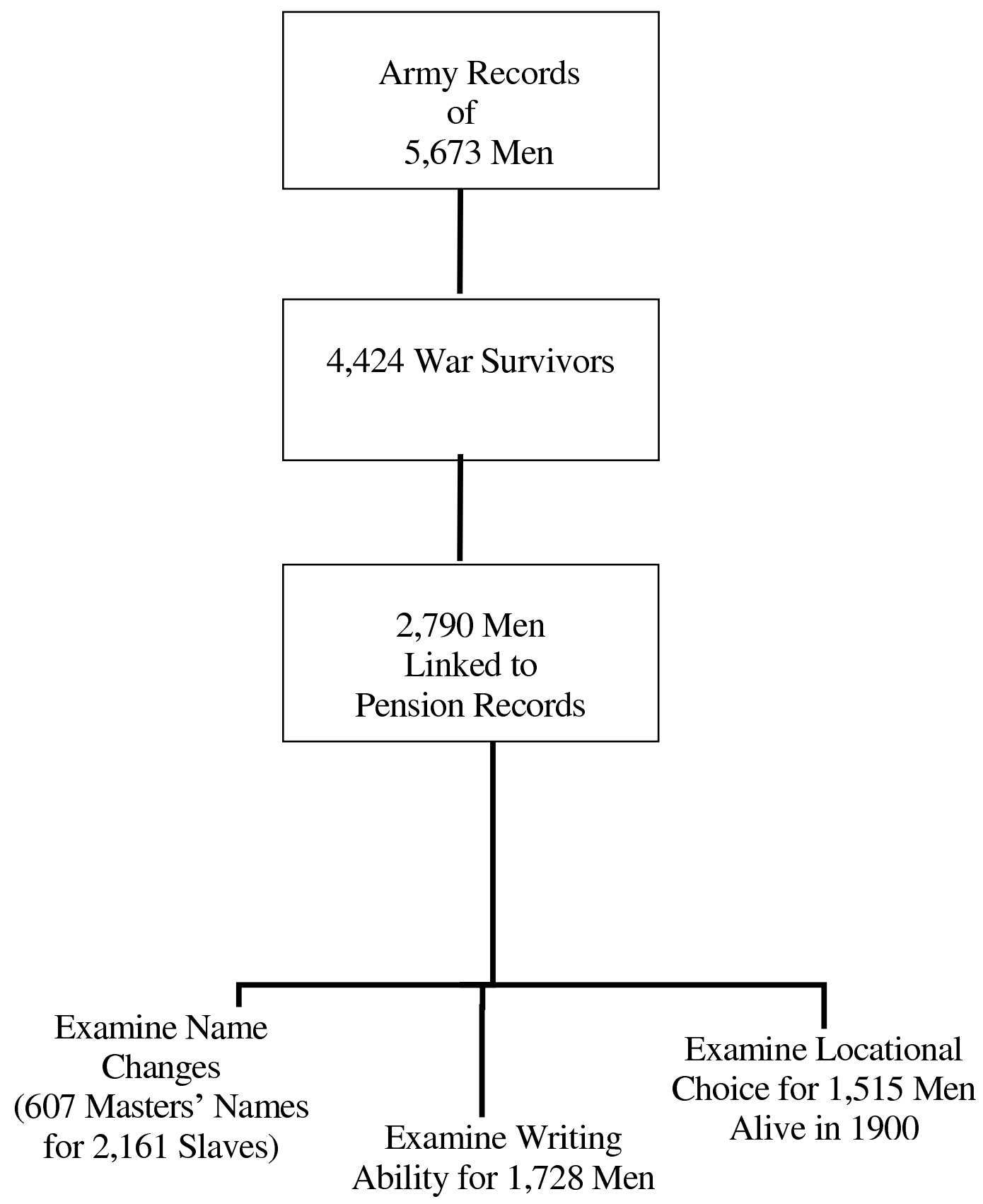

